\title{
7. The opposition
}

\section{GWYNNETH SINGLETON}

In a two-party unicameral parliament, the official opposition is deemed to be the largest majority party that is able to assume office if the government should resign (McKay 2004:247-8). In Australia's bicameral system, where the government is formed by the majority party in the House of Representatives, the official opposition is 'the main non-government party in that chamber' (Parliamentary Education Office 2010:17.1). After the 2007 federal election, when the Australian Labor Party (ALP) won government, the Coalition parties, being the significant minority grouping in the House of Representatives, formed the official opposition.

A government-opposition relationship is determined by the relative party numbers in the House of Representatives and reflected in the physical seating pattern of the parties facing each other across the House (Michaud 2000:74). The relationship has, however, a significant broader political meaning because it maintains and reinforces the competitive and adversarial environment implicit in Australia's majoritarian form of democracy. The adversarial status of the parties is contextualised by the fact that the opposition does not have the numbers to defeat the government, it cannot influence the legislative program, its function is to oppose (Birch 1978:167) and the job of the Leader of the Opposition is to contest government policy (Hawker 2008:11). This is certainly true given that an opposition predominantly responds to government legislation and government policy (Birch 1978:167), and its critical scrutiny of government performance is mostly negative because its activities are directed towards the electorate with the primary intent of destroying the credibility and the electoral prospects of the government (Bach 2003:243).

These factors could imply the relative powerlessness of an opposition visa-vis the government, with little opportunity for an opposition to influence government policy. An opposition can, however, hold a government to account by raising issues and exposing government policy to criticism in the Parliament; matters that are then taken up by the media can force a government to reappraise its approach to a particular policy. For example, the opposition's use of Question Time to probe the Rudd government about critical problems with its roof 
insulation installation scheme and media coverage of related fires and deaths largely contributed to the cessation of the program. The bicameral nature of the Australian Parliament - with its powerful senate elected by proportional voting - means the government of the day is less likely to have a majority. This can offset the apparent powerlessness of the opposition (Kaiser 2008:33) because it has the capacity to block or amend government legislation.

The question of whether an opposition is limited to opposing the government is investigated in this chapter by assessing the capacity of the opposition to influence government policy during the legislative process, particularly in relation to the Senate. It is beyond the scope of the chapter to examine every bill that has passed through the Parliament, so relevant examples have been used to draw out the arguments.

First, however, the significance of the leader in the contest between the opposition and the government requires an examination of the reasons for the three leadership changes that occurred during the period of the Rudd government between November 2007 and 24 November 2009.

\section{The opposition: significance of the leader}

The media focus on the leaders of the parties contending for office in Australian federal elections means that how a leader performs, either as prime minister or as opposition leader, can affect the result of a federal election (Senior and van Onselen 2008:226). The significance of the performance of the leader as a determinant of electoral success is indicated by the inclusion in regular political polling of questions asking respondents to identify whether the incumbent Prime Minister or the Leader of the Opposition is their preference for prime minister. This poll has been used by political analysts and the media to judge the performance of the respective leaders, and a leader of the opposition who fails to make headway against the government is unlikely to survive (Hawker 2008:5-6). It will be seen below that poor showings in the preferred prime minister polls and the indicative or notional two-party preferred result for the major parties led to the replacement of two leaders of the opposition during the period under review. The existence of potential rivals and a lack of cohesion brought about by internal division between conservative and moderate members of the Liberal Party were also factors in that process.

When John Howard lost his seat of Bennelong at the October 2007 election, the parliamentary Liberal Party had to select a new leader. Heir apparent, Peter Costello, surprisingly announced that he would 'not seek' nor 'would he accept' a nomination to be opposition leader (Costello 2008), and former Howard government senior ministers Alexander Downer and Philip Ruddock also 
decided not to contest the leadership. The ballot on 29 November 2007 between Brendan Nelson and Malcolm Turnbull (Tony Abbott withdrew because he did not have sufficient support) was won by Nelson with 45 votes to 42 (Wanna 2008a:294). Costello's presence on the backbench, however, fuelled continuing speculation about his leadership aspirations.

\section{Brendan Nelson}

Brendan Nelson, a 'small-c' conservative considered progressive on social issues (ABC 2007), was elected Leader of the Opposition as the result of a backroom deal brokered by conservative Liberal senate leader, Nick Minchin, with six West Australian members to give Nelson the numbers to win. Minchin and other conservatives gave their support to Nelson because they were intent on blocking moderate Malcolm Turnbull, whom some in the party considered to be 'a dangerous leftie' (MacCallum 2008:15), and, in particular, because of Turnbull's declaration that Howard should have said 'sorry' to Indigenous Australians over the Stolen Generations issue (Wright 2007). As leader, Nelson's approach to policy became wedged between his need to shore up his support with the conservative right to preserve his leadership against a potential challenge from Turnbull and to remain electorally relevant on social policy (Milne 2008a).

No opposition leader elected directly after a federal election had stayed in the office long enough to win a federal election (MacCallum 2008:12). Nelson was handed the 'poisoned chalice' (Wright 2007) of taking on the job of renewal and revitalisation of a party that had suffered defeat after 12 years in office and faced a popular, newly elected government. His inability to create a strong profile, his failure to lift the Coalition in the polls, and mixed responses to policy issues gave his conservative critics within the party the ammunition to attack his leadership.

The difficulties Nelson experienced in managing this situation are evident in his response to the Rudd government's apology to the Stolen Generations. Conservatives within the party opposed the apology because they considered the current government was not responsible for the actions of previous generations, although more moderate members were more supportive. Nelson approached the issue by seconding the government's apology yet including statements in his speech that the present generation did not own the actions nor should it feel guilty for what was done in the past, often with the best of intentions (Nelson 2008a:174-5). His statement caused people in the Parliament and thousands watching on television to turn their backs and 'people booed, hissed and shouted' during his speech (The Age 2008a). He was criticised publicly and from within his own party for diffidence in dealing with the issue and displaying a lack of leadership (MacCallum 2008:12; Wanna 2008b:611). His 
popularity as preferred prime minister slumped to 7 per cent and the Coalition's notional two-party preferred vote dropped to 37 per cent (see Table 7.1), leading to speculation about a possible leadership challenge (Wanna 2008b:615).

Nelson's approval rating as preferred prime minister peaked at a low 17 per cent at the beginning of June 2008 (Table 7.1), but this reflected public discontent with the government over rising petrol prices rather than increased support for Nelson (Shanahan 2008a). His propensity to 'flip-flop' on policy issues (Wanna 2009a:262) including climate change evoked 'enormous unhappiness' in the shadow cabinet (Shanahan 2008b). When Nelson withdrew the Coalition's support for the government's emissions trading scheme, the government responded that he could not be taken seriously as he had 'already changed his position seven times' (McManus 2008).

Nelson's muddled performance on policy, his poor standing as preferred prime minister and the relative weakness of the opposition compared with the government in two-party polling created the conditions for a leadership spill.

Table 7.1 Brendan Nelson's performance in the polls (per cent).

\begin{tabular}{l|l|l|l} 
Date of poll & $\begin{array}{l}\text { 29 February - 2 } \\
\text { March 2008 }\end{array}$ & $\begin{array}{l}\text { 30 May - 1 22-24 August 2008 } \\
\text { June 2008 }\end{array}$ \\
$\begin{array}{l}\text { Preferred prime } \\
\text { minister }\end{array}$ & 7 & 17 & 14 \\
\hline $\begin{array}{l}\text { Notional two- } \\
\text { party preferred } \\
\text { vote, Coalition }\end{array}$ & 37 & 43 & 44 \\
\hline
\end{tabular}

Source: Newspoll/The Australian (2010).

Potential rivals for the Liberal leadership were Malcolm Turnbull, who reportedly had not readily accepted his loss to Nelson (Wanna 2008a:295), and Peter Costello, 'the leader-who-might-have-been-or-still-might-be' (Hawker 2008:10). As Shadow Treasurer, Turnbull was constrained by the convention of cabinet collective responsibility from publicly criticising Nelson, but this did not prevent him from doing so in private. A leaked email from Turnbull to Nelson opposing the opposition leader's proposal for a reduction in the fuel excise by five cents a litre fuelled speculation about a leadership challenge. Costello's refusal to challenge Nelson unless others put themselves forward (Wanna 2009a:264) inhibited Turnbull from standing against Nelson because it would draw Costello into the contest and he was likely to win any ballot between them (Grattan 2008). The way was cleared for Turnbull when Costello announced his departure from federal politics on 10 September (Sydney Morning 
Herald 2008). Nelson's tenure as Leader of the Opposition came to an end on 15 September 2008 when he lost a pre-emptive spill he had brought on to resolve the leadership issue; Turnbull won by 45 to 41 votes (Wanna 2009a:264).

\section{Malcolm Turnbull}

Turnbull, a moderate, 'small-l' liberal, had lost his 2007 challenge to Nelson because a group of conservatives who considered him too far to the left had blocked his run for the leadership. At the time of his 2008 challenge, only about one-third of Liberal party-room MPs were considered moderates (Kerr 2008), which indicates that Turnbull had won the leadership with the support of sufficient conservative Liberal MPs to secure him the victory. Those who did so considered he could do a better job than Nelson by better articulating the party's policies and principles and would 'take the fight up to Labor' (AAP 2008). Internal party politics, however, was also a factor, as members of the NSW right are believed to have supported Turnbull because Nelson supported changes to the NSW party's constitution that would have diminished the conservatives' dominance in that division.

Turnbull's leadership created the paradox of a substantively conservative party with a small-l liberal leader (Kerr 2008). Many pro-Howard conservative MPs had difficulty accepting Turnbull because of his moderate stance and his personality (Kelly 2008). He 'bulldozed his way into the leadership' (Kelly 2008) with a 'crash through or crash' approach to politics (Barns 2010) and lacked the consultative, team-bonding skills deemed necessary to unite the philosophically divided party (Kelly 2008). His leadership was characterised by poor people skills, a 'tremendous ego', 'withering contempt' (Waterford 2008) and 'arrogance' (Milne 2008b). These factors sowed the seeds of his later destruction.

Turnbull's leadership began on a promising note with a small lift in the polls (Table 7.2), but the onset of the global financial crisis (GFC) in September 2008, the government's restorative stimulus package and tensions between conservative and liberal factions within the parliamentary Liberal Party made it difficult for him to make further headway. He upset the party's right-wing conservative faction when he appointed moderates to key positions in the parliamentary party (Franklin and Taylor 2009; Shanahan and Kenny 2009), sacked conservative Senator Cory Bernardi from the shadow cabinet for making derogatory remarks about opposition frontbencher Christopher Pyne (Karvelas 2009) and publicly contradicted statements by Tony Abbott on opposition pension policy and Andrew Robb on climate change policy (Franklin and Taylor 
2009). The Liberal party room became unruly, members and senators criticised Turnbull's domineering leadership style and divisions emerged over policy (Wanna 2009b:587).

Turnbull's political standing deteriorated after his mishandling of the 'OzCar affair'. OzCar was established by the Rudd government to provide funding assistance to car dealers unable to access credit as a result of the GFC. On 4 June 2009, Turnbull questioned the Prime Minister in Parliament on whether he or the Treasurer had made representations for OzCar assistance on behalf of Queensland car dealer John Grant Motors (Turnbull 2009a:5756). The issue was dubbed 'Utegate' because John Grant had lent the Prime Minister a utility to use within his electorate (Senate Privileges Committee 2009:1.8). When Godwin Grech, a Treasury public servant responsible for OzCar, told a Senate Economics Legislation Committee inquiry that the initial contact he had received regarding John Grant had come in an email from the Prime Minister's office (Grech 2009:E17, E38), Turnbull accused Rudd and Treasurer, Wayne Swan, of 'cronyism, patronage and abandonment of ethical standards' and the Treasurer of misleading Parliament (Turnbull 2009b:6665).

An Australian National Audit Office (ANAO 2009:14-15) inquiry found there 'was no evidence that either the Prime Minister or his office' had played a role in any representations made to Treasury, nor had the 'Treasurer or his office applied any pressure on Treasury' to give the dealer preference over other applicants. Grech, a 'Liberal sympathiser' who had provided information to Turnbull and Liberal Senator Eric Abetz on a number of issues (Maley 2010), had fabricated the email upon which the opposition based its attack on the Prime Minister and the Treasurer (Senate Privileges Committee 2009:1.4, 1.8, $2.4,2.63,2.10)$. Turnbull's poor handling of this issue weakened his leadership (Eltham 2009), as both his standing as preferred prime minister and support for the Coalition fell (see Table 7.2).

Differences between conservatives and moderates over the opposition's response to the Rudd government's carbon pollution reduction scheme (CPRS), discussed below, caused a schism in the party room that brought about the challenge that toppled Turnbull. One Liberal MP commented that politics 'isn't a winner-takeall business deal. When you lead a political party you have to take people with you and you have to accept compromise. That's part of the job- not to divide and rule' (Franklin 2009a). When Turnbull refused to adopt a compromise position proposed by conservatives Tony Abbott and Nick Minchin to refer the CPRS bills to a senate committee, a number of shadow ministers, including Abbott and Minchin, resigned (Kelly 2009a; Prasser 2009). Turnbull persisted in upholding the deal he had made with the government despite a deluge of emails and protests from the grassroots of the Liberal Party calling for the CPRS legislation to be delayed (Berkovic 2009) and a similar statement by climate 
change spokesman, Andrew Robb (Franklin and Taylor 2009). Turnbull's prospects for holding on to the leadership were undermined by polling showing 60 per cent of Australians were against the government rushing the CPRS (Milne 2009). Turnbull's approach and the hostility of conservatives within the party to his moderate views finally caused his unmaking.

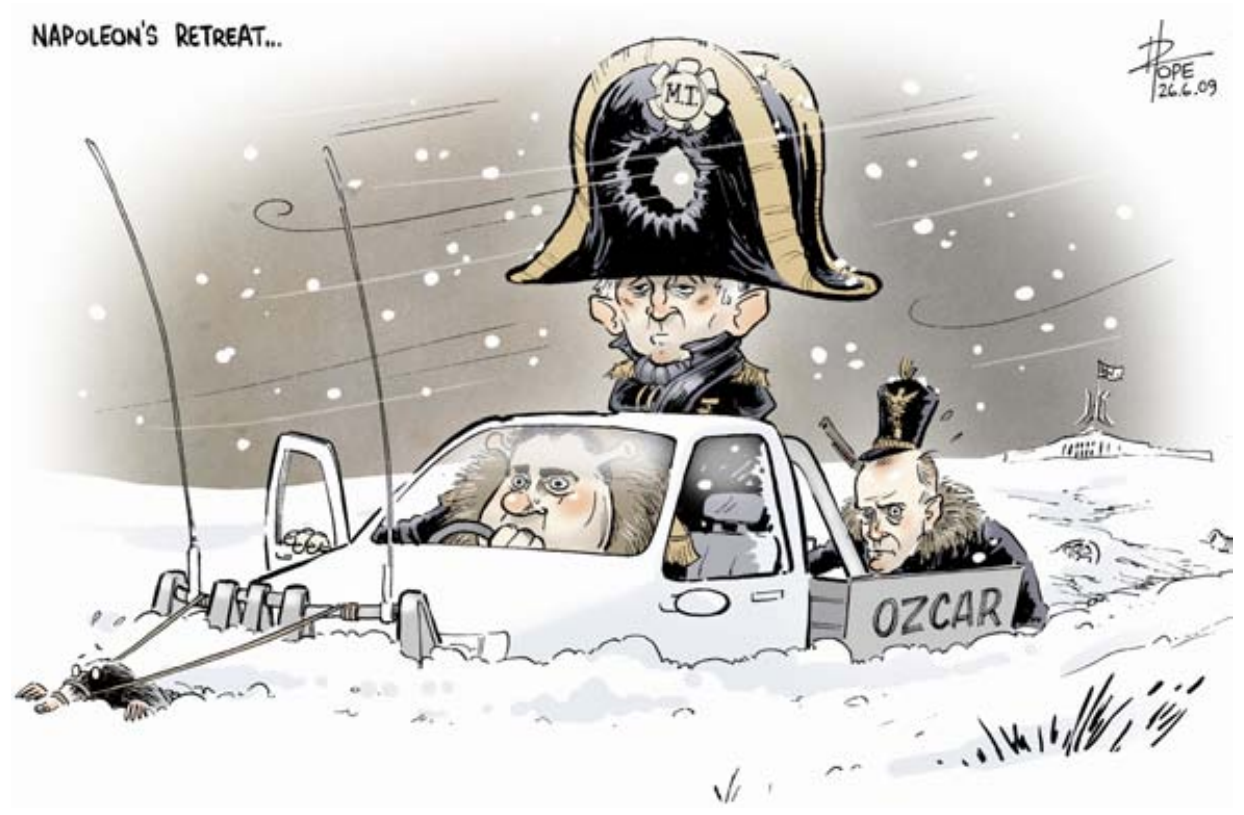

Source: David Pope, The Canberra Times, 26 June 2009

Costello, who had continued to be promoted as a contender for the leadership, ceased to be a 'weapon of mass distraction' (Wanna 2009a:287) when he announced on 7 October 2009 that he was retiring from Parliament (Costello 2009). The leadership challenge came from conservative anti-Turnbull forces concerned that he was taking the party too far to the left and climate change sceptics. It was described as 'a factional war between conservatives and small-1 liberals' (Grattan 2009) and 'an ambush on the leader' (Murphy 2009). The move was supported by Liberal MPs who were sympathetic to an emissions trading scheme but were doubtful about the government's rush to proceed before the outcomes of the Copenhagen conference were known. Members were also concerned at what many perceived to be Turnbull's ego-driven leadership style. Conservative Kevin Andrews, a central player in the leadership crisis (Murphy 2009), challenged Turnbull for the leadership on 24 November, but lost by 35 votes to 48 . Some members of the parliamentary party, however, still wanted Turnbull out of the leadership (Turnbull 2009c). His standing in the polls declined (Table 7.2), with more Liberal Party supporters disapproving than approving of his leadership (Colebatch 2009). Conservative Tony Abbott moved a spill motion (Franklin 2009b) and put himself forward as a candidate, 
as did Joe Hockey, a moderate supporter of the emissions trading scheme. In the ballot held on 1 December, Hockey was eliminated and the final ballot between Turnbull and Abbott was won by Abbott 42 to 41 (Sharp 2009). On 6 April 2010, Turnbull announced he would resign from the House of Representatives, but on 1 May 2010 he changed his mind and announced that he had decided to stay.

Table 7.2 Malcolm Turnbull's performance in the polls (per cent)

\begin{tabular}{l|l|l|l|l}
$\begin{array}{l}\text { Date of poll } \\
\begin{array}{l}10-12 \\
\text { October 2008 }\end{array}\end{array}$ & $\begin{array}{l}\text { 26-28 June } \\
2009\end{array}$ & $\begin{array}{l}\text { 24-26 July } \\
2009\end{array}$ & 27-29 November 2009 \\
$\begin{array}{l}\text { Preferred } \\
\text { prime } \\
\text { minister }\end{array}$ & 26 & 18 & 16 & 14 \\
\hline $\begin{array}{l}\text { Notional } \\
\text { two-party } \\
\text { preferred } \\
\text { vote, } \\
\text { Coalition }\end{array}$ & 45 & 44 & 43 & 43 \\
\hline
\end{tabular}

Source: Newspoll/The Australian (2010).

\section{Tony Abbott}

Even though Tony Abbott won the leadership ballot by only one vote, his accession to the leadership brought the conservatives back into ascendancy within the party, and he replaced moderates in the shadow ministry with the hardline conservatives who had worked to topple Turnbull (Coorey 2009). He has been described as a 'conviction' politician, clever and populist, a 'social conservative', a 'natural pugilist', a 'fitness fanatic', and 'unable to conceal his beliefs or blunders with spin' (Kelly 2009b). His Catholic conservativism, strongly influenced by B. A. Santamaria, a prominent activist with the Catholic National Civic Council (Abbott 2009:11), was considered likely to prove a disincentive for women voters (Kelly 2009b).

Abbott's keen approach to physical sporting pursuits became front-page news when he was photographed just days after taking over the leadership emerging from the surf in a pair of red Speedo swimming trunks, commonly known as 'budgie-smugglers' - an image caricatured by the nation's cartoonists and comedians ever since. In March, reporters followed the progress of 'Iron Man Abbott' in a triathlon and, in April, a Lycra-clad Abbott was again in the news when he participated in a Melbourne-Sydney bike ride. 
According to Abbott, political parties need some 'hard men' and he developed a reputation as the 'attack dog' of the Howard government (Abbott 2009:21). Not surprisingly, he took a more aggressive approach in opposing the Rudd government than his two predecessors (Daley 2010). The fact that his leadership opened up a wider divide in the political debate between the government and the Coalition was a function of this approach and it was also in keeping with Abbott's view that philosophical arguments assume more significance because the opposition's job is 'to clarify its own thinking rather than govern the country' (Abbott 2009:53). He recognised that the necessity to be viewed as a valid alternative government must be a constraint on unfettered political comment (Dusevic 2010a). His leadership came under critical scrutiny in May 2010 when he stated on the ABC's 7.30 Report that sometimes in the heat of discussion he went 'a little bit further than you would if it was an absolutely calm, considered, prepared, scripted remark, which is one of the reasons why the statements that need to be taken absolutely as gospel truth are those carefully prepared scripted remarks' (ABC 2010a). In a critical editorial, The Australian (2010) commented that Abbott too often offered 'flippancy rather than gravitas', that he had 'the grit' and 'an ironman certificate to prove it' but, it was pointed out, 'politics is not a bike ride, and energy alone will not get $\mathrm{Mr}$ Abbott across the line'.

Abbott's aggressive style and his view that an election could not be won without a fight, with the opposition providing an alternative and not an echo to the government (Rodgers 2009), contextualised his attacks on the performance of both the Rudd and the Gillard governments. One of Abbott's first moves as leader was to vote down the CPRS bills in the Senate (with the support of the Greens and Senators Steve Fielding and Nick Xenophon). The Coalition's policy became direct action to reduce carbon dioxide emissions 'without the need for a great big new tax' (Liberal Party of Australia 2010a). Abbott pledged to restore the budget to surplus through cuts to government expenditure rather than higher taxes, with a commitment to reject Labor's 'massive new mining tax' (Abbott 2010). The Coalition rejected Rudd's population target of 36 million and promised that their migration program would be 'consistent with a sustainable population growth path' (Liberal Party of Australia 2010b).

The opposition and the Rudd-Gillard governments advanced many similar policies although there were differences in the detail. These included support for Australia's commitment to Afghanistan, paid parental leave, and offshore processing and detention of asylum-seekers (although the 
Liberals would have restored temporary protection visas and would have 'returned boats and/or their passengers to their point of departure or an alternative third country destination') (Liberal Party of Australia 2010c).

Abbott's performance in the polls was better than his predecessors'. In May 2010, the Coalition was in a winning position with 50 per cent of the two-party preferred results, and Abbott had improved his preferred prime ministerial rating to 37 per cent (Table 7.3). Some of this improvement was due to the penetration of Abbott's attacks on Labor's spin and Rudd's poor performance (Dusevic 2010b). More significant was the poor performance of the Rudd government, including policy reversals on climate change and childcare centres, an increase in tobacco tax, problems with the insulation installation and the Building the Education Revolution (BER) building programs, interest rate rises, and a heated campaign from the mining industry against the mining resources profits tax. After Julia Gillard became Prime Minister, Abbott fell back in the preferred prime minister polls, to 27 per cent, in the two days leading up to the announcement of the federal election and in the two-party preferred poll, to 45 per cent. Once the campaign got under way, however, his support as preferred prime minister in polling undertaken on 23-25 July increased to 34 per cent and the Coalition's two-party preferred vote also increased, to 48 per cent. A Herald/Nielsen poll published on 31 July saw Labor leading the two-party preferred vote by 52 per cent to 48 per cent and Abbott's approval rating as preferred prime minister reducing the gap at 41 per cent, with Julia Gillard on 49 per cent. Immediately prior to the election Abbott's rating as preferred prime minister stood at 37 per cent. At no time had he surpassed either Rudd or Gillard in this regard.

The 2010 election resulted in a hung parliament and even though Abbott failed to form government, his performance in bringing the Coalition so close was a significant achievement. He ran a disciplined campaign with a united team and benefitted from Labor's policy mishaps. He is credited with pressuring Labor to the point where it ruthlessly dumped Rudd in favour of Gillard. He responded to criticism that he ran a negative campaign by pointing to his 'strong, positive agenda' to 'end the waste', 'pay back the debt', 'stop the big new taxes' and 'stop the boats' (Hartcher 2010). He was returned as Leader of the Opposition unopposed. 
Table 7.3 Tony Abbott's performance in the polls (per cent)

\begin{tabular}{|c|c|c|c|c|c|c|c|}
\hline $\begin{array}{l}\text { Date of } \\
\text { poll }\end{array}$ & $\begin{array}{l}26-28 \\
\text { March } \\
2010^{*}\end{array}$ & $\begin{array}{l}14-16 \\
\text { May } \\
2010 *\end{array}$ & $\begin{array}{l}18-20 \\
\text { June } \\
2010^{*}\end{array}$ & $\begin{array}{l}16-18 \\
\text { July } \\
2010 *\end{array}$ & $\begin{array}{l}23-25 \\
\text { July } \\
2010 *\end{array}$ & $\begin{array}{l}31 \text { July } \\
2010 \text { * * }\end{array}$ & $\begin{array}{l}\text { 17-19 } \\
\text { August } \\
2010^{*}\end{array}$ \\
\hline $\begin{array}{l}\text { Preferred } \\
\text { prime } \\
\text { minister }\end{array}$ & 27 & 33 & 37 & 27 & 34 & 41 & 37 \\
\hline $\begin{array}{l}\text { Coalition } \\
\text { notional } \\
\text { two- } \\
\text { party } \\
\text { preferred } \\
\text { vote }\end{array}$ & 44 & 50 & 48 & 45 & 48 & 52 & 49.8 \\
\hline
\end{tabular}

Sources: * Newspoll/The Australian (2010); ${ }^{* *}$ AAP (2010).

\section{Opposition influence over government policy}

Because the government had a majority in the House of Representatives, the opposition in that house was restricted to raising issues and probing government performance through Question Time and debate. The opposition did not oppose all legislation because there were many issues on which there was bipartisan agreement. For example, until 1 April 2010, of the 438 bills that had passed the House of Representatives, only 80 (or about 18 per cent) required a division (Department of the House of Representatives 2010). This does not necessarily mean that the opposition agreed entirely with those uncontested bills, but it let the bills pass through the House of Representatives without a division. Bills relating to run-of-the-mill machinery-of-government issues usually have bipartisan support.

The situation in the Senate was different because the opposition's majority in that house until 30 June 2008 meant it could amend or vote down government legislation. Even so, the Senate passed 84 government bills and only five were negatived or discharged from the Notice Paper (Senate 2008a). This pattern continued after 1 July 2008 when the opposition required the support of one of the crossbench senators to vote down government bills and two to pass amendments or pass its own bills. For the remainder of 2008, 80 bills were agreed to and only eight were negatived or discharged from the Notice Paper (Senate 2008a). Not all the bills passed, however, were uncontested by the opposition; five were passed when the Greens and the two independent senators voted with the government (Senate 2008b). As an example, the government's bill to lift the luxury car tax to 33 per cent was defeated in the Senate in 2008 
when Family First Senator, Steve Fielding, voted with the opposition against the bill. It passed, however, after Senators Fielding and Xenophon negotiated amendments with the government (The Age 2008b).

Despite having a senate majority, the opposition's capacity to have any real influence on the policy agenda was constrained by government control of the legislative program. For example, Liberal MHR Petro Georgiou's Private Member's Bill to establish an independent reviewer of the Terrorism Laws Bill 2008 was defeated in the House of Representatives, passed the Senate on 13 November 2008 with the support of Senators Fielding and Xenophon, but was not listed for consideration after it was reintroduced into the House of Representatives on 24 November 2008.

In 2009, Rudd government ministers complained that they were dealing with 'the most obstructionist opposition in 30 years' (ABC 2010b) because the Senate voted down 41 bills. The actual outcome, however, was not significantly different from the previous years of the Rudd government because some of those bills subsequently passed and 11 bills relating to the CPRS scheme were voted down twice (Senate 2009a). Harry Evans makes this same point in Chapter 5 of this volume.

\section{Negative influence: blocking bills}

Voting down government bills in the Senate is a negative action because it denies the government its preferred policy but does not necessarily influence government policy. The government's bill to means test the private health insurance rebate was defeated in the Senate on the combined vote of the opposition, the Greens and the two independents (Senate 2009b:6184). The government threatened a double dissolution if the bill was defeated in the Senate a second time (Breusch 2009), but the threat of an early election did not dissuade the opposition from defeating the legislation in the Senate a second time with the support of Family First Senator, Steve Fielding (Senate 2010:1384).

\section{Positive influence: amending bills}

The opposition had the opportunity to make a positive contribution to policy by passing amendments to government bills using its senate majority until 30 June 2008 or with the support of two crossbench senators after 1 July 2008. The Broadcasting Legislation Amendment (Digital Television Switch-Over) Bill 2008 was amended in the House of Representatives to delete a clause inserted by the opposition and Senators Fielding and Xenophon that would have required the government to report to each House of the Parliament the action taken to 
identify and rectify digital transmission black spots. The Senate did not agree to the government's amendment and, as the government did not insist on its amendment, the opposition's amended policy was retained.

Nevertheless, opposition influence is marginal if limited to minor amendments. When the opposition used its senate majority to include a review process in the legislation to establish a teen dental plan and a new dental benefits schedule, the government did not think that the amendment moved in the Senate added sufficient value but was happy to concede if the opposition insisted it be included in the bill (Roxon 2008).

If the government refuses to accept opposition-derived senate amendments, the opportunity for any positive influence is lost because the options are to let the legislation pass through the Parliament without those amendments or to vote down the bill in the Senate. The Families, Housing, Community Services and Indigenous Affairs and Other Legislation Amendment (2008 Budget and Other Measures) Bill 2008 is a good example. It included, amongst other measures, the introduction of a means test for Family Tax Benefit Part B and the baby bonus; the requirement that claimants of the Commonwealth Seniors Health Card provide their tax file numbers (TFNs) (Schedule 3); and an increase in the Partner Service Pension qualifying age for males from fifty to sixty years and for females from fifty years to fifty-eight years and six months (Schedule 5). The opposition used its majority in the Senate to amend the bill to introduce a tapered rate for the baby bonus for incomes in excess of $\$ 150000$, to express concern at the imposition of a means test on the Family Tax Benefit, and to negate Schedules 3 and 5 (Senate 2008c:3252).

After aggressive lobbying of senior ministers by the not-for-profit sector (ABC 2008a), the government introduced its own amendment to the bill to reverse changes to the Fringe Benefit Tax rules implemented by the Howard government in 2006 that had reduced the incomes of charity and community-sector workers. The opposition supported the amendment in order to provide certainty to workers in the charity sector (Senate 2008c:3260). An opposition amendment for a review of operations of the amendments to the act was also passed and the bill was referred back to the House of Representatives.

The government accepted the Senate's amendments criticising the baby bonus and the Family Tax Benefit Part B and the inclusion of the review mechanism. These were marginal changes that did not affect the substance of the bill. It refused, however, to exclude Schedules 3 and 5 relating to the TFN and the Partner Service Pension. Despite its vehement disagreement with these two proposals, the opposition in the Senate did not insist on these amendments 
for the politically pragmatic reason that it would have meant that charity and community workers would have lost up to $\$ 100$ a week from 1 July if the bill was not passed before the Senate rose for its winter break (Abbott 2008:5958).

The opposition also did not persist with its senate amendments to the NationBuilding Funds Bill 2008 after they were rejected by the government despite significant disagreement within Coalition ranks. The bill had been vehemently opposed by the Coalition, particularly the Nationals, because it removed the Communications Fund set up by the Howard government in 2005. An opposition amendment to delete this provision passed by the Senate with the support of Senators Fielding and Xenophon was rejected by the government. When the bill returned to the Senate, despite vigorous and angry debate from Liberal and National senators, the Liberal leadership did not insist on its amendments for the politically strategic reason that if it had done so the government would 'spend the next two months falsely asserting all over the country that we are responsible for denying infrastructure funding to every road, bridge and port in the country' (Minchin 2008:8336). Many Coalition senators, including Liberal Leader in the Senate, Nick Minchin, vented their displeasure at this about-face by not being present in the Chamber when the vote was taken, and four National senators and two Liberals crossed the floor in protest. Only five Liberal senators voted with the government. This discord within Coalition ranks-regarded as 'open rebellion' against Leader of the Opposition, Malcolm Turnbull (ABC 2008 b) - was a forerunner to the more significant split over climate change that led to the downfall of Turnbull's leadership, discussed above.

\section{Influence through cooperation or compromise}

Meaningful input to government policy occurred when the government, having failed to get the support of the crossbenchers, turned to the opposition to pass its bills through the Senate. Again, practical politics was a reason for its decision to pass the bill. The opposition had voted with Senator Fielding to prevent the exclusion of part-time work as eligibility for independence status under the Youth Allowance (Social Security and Other Legislation) Amendment (Income Support for Students) Bill 2009 (No. 2) on the basis that it disadvantaged rural and regional families and students who had done this type of work in the previous year when it was allowable. The government negotiated changes to the bill with the Greens and Senator Xenophon to get their support, but was not able to secure the critical vote of Senator Fielding. The failure to pass the bill meant that 150000 students entering university in first semester 2010 would not receive scholarships. The government then negotiated with the opposition and agreed to amend the bill so that students who lived in very remote, remote or outer regional centres who had to move away from home to study would be eligible for the Youth Allowance under the existing independence test. The 
bill then passed the Senate with the opposition's support (Gillard 2010). When Senator Fielding berated the Coalition for selling out on inner rural students (Sydney Morning Herald 2010), Senator Mason reminded him that the Coalition was in opposition and, although the deal was not perfect and a lot of his colleagues were not happy about it, it was worth hundreds of millions of dollars over the next 10 years or so to enable rural students to go to university. 'I think the Coalition overall has done a very good job in securing what it can for rural students', he said (Mason 2010:2056).

\section{Conclusion}

The significance of political polling as a central factor in maintaining or losing the Liberal leadership is evident from the way in which the Liberals brutally disposed of Brendan Nelson and Malcolm Turnbull when they failed to make headway against the government in the two-party preferred vote and preferred prime minister poll results. In Turnbull's case, poll results provided justification for the spill, but it was underpinned by the ideological split between the conservatives and moderates in the party that came to a head over Turnbull's support for the government's CPRS legislation. The driving force of electoralism as a critical factor in maintaining the leadership is captured in Abbott's statement that 'the only really happy opposition is one that's convinced it's on the verge of winning government' (Abbott 2009:54). ${ }^{1}$

The proposition that an opposition in a two-party system in the Westminster tradition is powerless to influence government policy, apart from raising issues in the Parliament and the media, has to be reconsidered in the context of Australia's bicameral system. During the term of the Rudd government, the opposition in the Senate was able to influence government policy by blocking or amending legislation, but the distinction has to be drawn between negative influence where the government refuses to accept the outcome and positive input where opposition amendments are accepted. Positive input was achieved when the government, for various reasons, accepted opposition amendments, although these were primarily of a minor nature. More substantive input was achieved when the government negotiated an agreed outcome with the opposition in order to get its bills through the Parliament after it failed to get the support of the Greens and Senators Fielding and Xenophon.

Brendan Nelson held the view that an opposition should not just oppose everything and that if a government was doing the right thing, the opposition

1 The same adage probably applies to the government, as we saw when Prime Minister, Kevin Rudd, was ousted when falling public support for his leadership and the party was seen to be a threat to the re-election of the Labor government. 
needed to say so (Nelson 2008b). In the Australian system, however, an opposition is in an adversarial relationship with the governing party. In this context, the opposition attacked the performance of the Rudd government at every opportunity in Question Time, in parliamentary debate and in the public arena through the media. It blocked and amended government bills in the Senate with which it disagreed. The opposition also has to provide voters with a choice by differentiating its policies from those of the government. In Abbott's words, the job of the opposition is 'to be an alternative, not an echo' (Rodgers 2009). This contextual framework of the relationship is captured by Abbott's stated determination to draw the battlelines between the opposition and the Labor government (Abbott 2009:182) and Gillard's incitement to Abbott when she became Prime Minister for him 'to bring it on'.

Gwynneth Singleton is an Adjunct Associate Professor at the University of Canberra.

\section{References}

Abbott, A. 2008. House of Representatives, Debates, 25 June.

Abbott, A. 2009. Battlelines, Melbourne University Press, Carlton, Vic.

Abbott, A. 2010. Leader of the Opposition Address to the Liberal Party Federal Council, 26 June, Liberal Party of Australia, Barton, ACT, <www.liberal. org.au/Latest-News/2010/06/26/Leader-of-the-Opposition-Address-to-theLiberal-party-Federal-Council.aspx $>$

Australian Associated Press (AAP) 2008. Australian National News Wire, 16 September, Australian Associated Press, accessed through EBSCOhost, Australia/New Zealand Reference Centre, Accession No. 74C429459612.

Australian Associated Press (AAP) 2010. 'Abbott leads Gillard in latest poll', Australian Associated Press, 31 July, <http://www.news.com. au/breaking-news/abbott-leads-gillard-in-latest-poll/story-e6frfku01225899282954\#ixzz0vK7BTuZl>

Australian Broadcasting Corporation (ABC) 2007. 'Brendan Nelson elected as opposition leader', PM, ABC Radio, 29 November, <http://www.abc.net.au/ pm/conent/2007/s2105607.htm> 
Australian Broadcasting Corporation (ABC) 2008a. 'Fringe benefits changes to hit low paid workers', ABC News, 17 June 2008, <http:/www.abc.net.au/ news/stories/2008/06/12/2276703.htm>

Australian Broadcasting Corporation (ABC) 2008b. 'Opposition disarray over dumping of Telstra fund', PM, ABC Radio, 5 December, <http://www.abc. net.au/pm/content/2008/s2439346>

Australian Broadcasting Corporation (ABC) 2010a. 'Abbott quizzed on mixed messages', 7.30 Report, ABC TV, 17 May, <www.abc.net.au/7.30/ content/2010/s2901996.htm>

Australian Broadcasting Corporation (ABC) 2010b. 'Ministers savage "just say no Abbott"', $A B C$ News, 10 March, <http://www.abc.net.au/news/ stroies/2010/03/10/2841751.htm>

Australian National Audit Office (ANAO) 2009. Representations to the Department of the Treasury in relation to motor dealer financing assistance, Audit Report No. 1 2009-10, Australian National Audit Office, Barton, ACT, <http://www. anao.gov.au/uploads/documents/2009-10_Audit_Report_1.pdf >

Bach, S. 2003. Platypus and Parliament: The Australian Senate in theory and practice, Department of the Senate, Canberra.

Barns, G. 2010. 'Malcolm Turnbull's small "l" liberalism leaves big legacy', The Drum Unleashed, ABC TV, 6 April, <http://www.abc.net.au/unleashed/ stores/s2865144.htm>

Berkovic, N. 2009. 'Climate deal sparks a new wave of Coalition frontbench resignations', The Australian, 27 November, <http://www.theaustralian. com.au/politics/climate-deal-sparks-a-wave-of-coalition-frontbenchresignations/story-e6frgczf-1225804365829>

Birch, A. 1978. The British System of Government, (Revised edition), George Allen \& Unwin, London.

Breusch, J. 2009. 'PM puts poll pressure on Turnbull', Australian Financial Review, 14 September.

Colebatch, T. 2009. 'Poll numbers turn against leader', The Age, 30 November, $<$ http://www.theage.com.au/natioal/poll-numbers-turn-against-leader20091129-jywi.htm>

Coorey, P. 2009. 'Climate change sceptics triumph', Sydney Morning Herald, 9 December, <http://www.smh.com.au/national/climate-change-scepticstriumph-20091208-khqb.html> 
Costello, P. (with Coleman, P.) 2008. The Costello Memoirs, Melbourne University Press, Carlton, Vic.

Costello, P. 2009. Statement concerning Higgins electorate, Official web site of Peter Costello, 7 October, <http://www.petercostello.com.au/press/ statement-concerning-higgins-electorate $>$

Daley, P. 2010. 'Abbott takes aim at a PM all at sea', National Times, 4 January, <http://www.nationaltimes.com.au/opinion/politics/abbott-takes-aim-at-apm-all-at-sea-20100201-lmgg.html>

Department of the House of Representatives 2010. List of bills passed by the House of Representatives in the 42nd Parliament, showing the bills on which the House divided, Email to G. Singleton, 1 April 2010, from Chamber Research Office, Department of the House of Representatives, Canberra.

Dusevic, T. 2010a. 'The battle within', The Weekend Australian, 20-21 March.

Dusevic, T. 2010b. 'Rudd on the slide', The Weekend Australian, 8-9 May.

Eltham, B. 2009. 'The political rip snorter that was 2009', newmatilda.com, 17 December, <http://newmatilda.com/2009/12/17/political-rip-snorter-2009>

Franklin, M. 2009a. 'Malcolm Turnbullunmoved as support dives', The Australian, 28 November, <http://www.theaustralian.com.au/news/nation/malcolmturnbull-unmoved-as-support-dives/story-e6frg6nf-1225804755606>

Franklin, M. 2009b. 'Joe Hockey set to take on Malcolm Turnbull', The Australian, 30 November, <http://www.theaustralian.com.au/news/joe-hockey-set-totake-on-malcolm-turnbull/story-e6frg6n6-1225805155171?from=public _ rss>

Franklin, M. and Taylor, L. 2009. 'Pressure builds on Malcolm Turnbull as Liberal infighting erupts', The Australian, 20 February, <http://www. theaustralian.com.au/news/nation/pressure-builds-on-turnbull/storye6frg6nf-111111889099072>

Gillard, J. 2010. Government delivers on youth allowance, Media release, 16 March 2010, Parliament House, Canberra, <http://www.deewr.gov.au/ Ministers/Guillard/Media/Releases/Pages/Article_100316_175824.aspx>

Grattan, M. 2008. 'No challenge by Turnbull, but wriggle room aplenty', The Age, 22 May, <http://www.theage.com.au/news/national/no-turnbullchallenge-but-wriggle-room-aplenty/2008/05/21?1211182895814.htm> 
Grattan, M. 2009. 'Minchin's emissions opposition a direct challenge to Turnbull', National Times, 20 November, <http://www.nationaltimes.com. au/opinion/politics/minchins-emissions-opposition-a-direct-challenge-toturnbull-20091119-iotb.html>

Grech, G. 2009. Senate Economics Legislation Committee, Reference: Car Dealership Financing Guarantee Appropriation Bill 2009, CPD Official Committee Hansard, 19 June, <http://www.aph.gov.au/hansard/senate/ committee/S12204.pdf>

Hawker, G. 2008. 'Between somewhere \& nowhere: Brendan Nelson as federal Liberal leader', Australian Quadrant, vol. 80, no. 2 (March-April), pp. 4-12.

Kaiser, A. 2008. 'Parliamentary opposition in Westminster democracies: Britain, Canada, Australia and New Zealand', The Journal of Legislative Studies, vol. 14, no. 1, pp. 20-45.

Karvelas, P. 2009. 'Turnbull sacks SA senator Cory Bernardi over Pyne claim', The Australian, 19 February, <http://www.theaustralian.com.au/news/ turnbull-sacks-senator-over-pyne-claim/story-01111118903519>

Kelly, P. 2008. 'A Liberal dose of hope', The Australian, 17 September, <http:// www.search.ebscohost.com>, Accession No. 200809171016549011.

Kelly, P. 2009a. 'Rebels with a lost cause', The Australian, 28 November, < http:// www.theaustralian.com.au/news/opinion/rebels-with-a-lost-cause/storye6frg6zo-1225804740400>

Kelly, P. 2009b. 'The great conservative revolt', The Australian, 2 December, $<$ http://www.theaustralian.com.au/news/opinion/the-great-conservativerevolt/story-e6frg74x-1225805945617>

Kerr, C. 2008. 'The man most likely to succeed', The Australian, 27 September.

Liberal Party of Australia 2010a. The Coalition's direct action plan: environment and climate change, Liberal Party of Australia, Barton, ACT, <http://www. liberal.org.au>

Liberal Party of Australia 2010b. Coalition rejects Prime Minister's 36 million population target, 29 April, Liberal Party of Australia, Barton, ACT, <http://www.liberal.org.au/Latest-News/2010/04/29/Coalition-rejects-PMspopulation-target.aspx $>$

Liberal Party of Australia 2010c. Restoring sovereignty and control to our borders: policy direction statement, 27 May, Liberal Party of Australia, Barton, ACT, <http://www.liberal.org.au > 
The Rudd Government

MacCallum, M. 2008. 'The nation reviewed', The Monthly, no. 33 (April), pp. $12-15$.

McKay, W. 2004. Erskine May Parliamentary Practice, (23rd edition), LexisNexis Butterworths, London.

McManus, G. 2008. 'Brendan Nelson warns of climate change economic doom', Herald Sun, 8 July, <http://www.heraldsun.com.au/news/liberals-warn-ofdoom/story-0-1111116850500>

Maley, P. 2010. 'Abetz admits Turnbull fed him Grech leaks', The Australian, 26 March.

Mason, B. 2010. Senate, Debates, 17 March.

Michaud, N. 2000. 'Designating the official opposition in a Westminster parliamentary system', The Journal of Legislative Studies, vol. 6, no. 4.

Milne, G. 2008a. 'Nelson wedges himself trying to please all', The Australian, 16 June.

Milne, G. 2008b. 'Malcolm Turnbull wins public support', Sunday Mail [Brisbane], 21 September, <http://www.couriermail.com.u|au/news/ national/public-warms-to-turnbull/story-e6freooo-1111117541090>

Milne, G. 2009. 'Malcolm Turnbull stance cops a poll axing', Sunday Telegraph, 29 November, <http:/www.dailytelegraph.com.au/news/ sunday-telegraph/malcolm-turnbull-stance-cops-a-poll-axing/storye6frewx0-1225804931826>

Minchin, N. 2008. Senate, Debates, 4 December.

Murphy, K. 2009. 'Nationals maverick sets course for lower house', The Age, 4 December, <http://www.theage.com.au/national/nationals-maverick-setscourse-for-lower-house-20091203k8tu-html>

Nelson, B. 2008a. House of Representatives, Debates, 13 February.

Nelson, B. 2008b. Transcript of interview with Geoff Hutchison, ABC 720 Perth, ABC Radio, <http://www.parlinfo/download/media/radioprm/M21Q6/ uploand_binary/m2161.pdf $>$

Newspoll/The Australian 2010. 'Political and issues trends', Newspoll/The Australian, <http://www.newspoll.com.au/cgi-bin/polling/display_poll_ data.pl>

Parliamentary Education Office 2010. 'Alternative government - the opposition', Our Government, no. 17, Parliamentary Education Office, Canberra, <http:// www.peo.gov.au/faq/faq_17.html> 
Prasser, S. 2009. 'Peter Costello's to blame for the leadership crisis tearing the party apart', The Australian, 1 December, <http://www.theaustralian.com. au/news/opinion/peter-costellos-to-blame-for-the-leadership-crisis-tearingthe-party-apart/story-e6frg620-1225805523074>

Rodgers, E. 2009. 'Abbott comes out fighting after leadership coup', $A B C$ News Online, 1 December, <http://www.abc.net.au/news/ stories/2009/12/01/2758345>

Roxon, N. 2008. House of Representatives, Debates, 23 June.

Senate 2008a. Senate Statistical Summary, Parliament of Australia, Canberra, <http://www.aph.gov.au/Senate/work/statistics/stats_sum/2008/s06.htm>

Senate 2008b. Senate, Debates, 26 August to 4 December.

Senate 2008c. Senate, Debates, 24 June.

Senate 2009a. Legislation Statistics 2009, Parliament of Australia, Canberra, <http://www.aph.gov.au/Senate/work/statistics/bus_senate/2009/ legislation/legis_stats.html>

Senate 2009b. Senate, Debates, 9 September.

Senate 2010. Senate, Debates, 9 March.

Senate Privileges Committee 2009. Matters arising from the Economics Legislation Committee Hearing on 19 June 2009 (referred 24 June and 12 August 2009), 142nd Report, 25 November, Senate Privileges Committee, Canberra, <http:// www.aph.gov.au/senate/committee/priv_ctte/report_142/index.htm>

Senior, P. and van Onselen, P. 2008. 'Re-examining leader effects: have leader effects grown in Australian federal elections 1990-2004?', Australian Journal of Political Science, vol. 43, no. 2 (June).

Shanahan, D. 2008a. 'Brendan Nelson's vision lost in carbon fog', The Australian, July 30, <http://www.theaustralian.com.au/news/brendans-vision-lost-incargon-fog/story-e6frg6no-1111117054261>

Shanahan, D. 2008b. 'Rudd pays personal toll for anger about petrol prices', The Australian, 3 June, <http://www.theaustralian.com.au/news/national/ruddpays-personal-toll-newspoll/story-e6frg6nf-1111116519902>

Shanahan, D. and Kenny, M. 2009. 'Liberal Senator Cory Bernardi demoted over Christopher Pyne', Adelaide Now, 19 February, <http://www. adelaidenow.com.au/news/sa-libs-sacking-sets-up-leadership-fight/ story-0-1111118902643> 
Sharp, A. 2009. 'Abbott wins Liberal leadership-by one vote', The Age, 1 December, <http://www.theage.com.au/national/abbott-wins-liberalleadership-by-one-vote-20091201-klva.html>

Sydney Morning Herald 2008. 'Costello says he is leaving politics', Sydney Morning Herald, 10 September, <http://news.shm.com.au/national/costellosays-he-is-leaving-politics-20080910-4d5h.html>

Sydney Morning Herald 2010. 'Youth allowance reforms all but passed', Sydney Morning Herald, 17 March, <http://www.smh.com.au/breaking-newsnational/youth-allowance-reforms/all-but-passed-20100317>

The Age 2008a. 'Liberal leader provoked outrage', The Age, 13 February, <http://www.theage.com.au/articles/2008/02/13/1202760367682.html>

The Age 2008b. 'Luxury car tax bill passes Senate', The Age, 24 September, $<$ http://www.theage.com.au/business/luxury-car-tax-bill-passes-senate20080924-4mqu.html>

The Australian 2010. 'Editorial', The Australian, 21 May.

Turnbull, M. 2009a. House of Representatives, Debates, 4 June, p. 5756.

Turnbull, M. 2009b. House of Representatives, Debates, 22 June, p. 6665.

Turnbull, M. 2009c. Doorstop interview, Rose Bay, NSW, 28 November, <http:// malcolmturnbull.com.au/Media/LatestNews/tabid/articleType/ArticleView/ articleId/695/Doorstop-Interview-Rose-Bay.aspx>

Wanna, J. 2008a. 'Commonwealth of Australia July to December 2007', Australian Journal of Politics and History, vol. 54, no. 2, pp. 289-341.

Wanna, J. 2008b. 'Commonwealth of Australia January to June 2008', Australian Journal of Politics and History, vol. 54, no. 4, pp. 609-62.

Wanna, J. 2009a. 'Commonwealth of Australia July to December 2008', Australian Journal of Politics and History, vol. 55, no. 2, pp. 261-315.

Wanna, J. 2009b. 'Commonwealth of Australia January to June 2009', Australian Journal of Politics and History, vol. 55, no. 4, pp. 584-92.

Waterford, J. 2008. 'Turnbull the great contradiction', Australian Policy Online, 18 September, <http://www.apo.org.au>

Wright, T. 2007. 'Backroom deal seals Nelson bid', The Age, 30 November. 